\title{
ARMY CAMP AND ORPHANS HOME
}

\author{
By DR. Charles E. SNyder ${ }^{2}$
}

Davenport was the location of five camps for the reception and training of recruits during the time of the Civil war." The first and the longest continued was Camp McClellan, situated on the bluffs, then just east of the city limits, now included within the incorporation and the site of its more pretentious residences. The camp was opened August 8, 1861. Five Iowa Regiments went out from Camp McClellan before it became a prison camp for recalcitrant Sioux Indians after the uprising in Minnesota.

Camp Joe Holt, which dated from August 22, 1861, was located between Thirteenth and Northern Avenue, now Kirkwood boulevard, between Perry street and Rock Island street, now Pershing avenue. Camp Herron was opened August 25, 1862, between Farnam street and Churchill's addition. Camp Hendershott began October 10, 1862, between Thirteenth and Locust streets north and south and Ripley and Scott streets east and west. Joe Holt and Hendershott did not last long.

Our present study is directed towards the fifth of these locations, Camp Roberts, opened July 14, 1863, which afterwards was known as Camp Kinsman. At the Iowa Soldiers' Orphans Home is a small stone marker with the inscription:

"Site of Camp Roberts During The Civil War.

Dedicated by Hannah Caldwell Chapter D.A.R., 1929."

There is nothing else evident to associate Gen. B. S. Roberts with the city where he lived in that fateful year of Gettysburg and Vicksburg.

\footnotetext{
1The Rev. Charles E. Snyder, Litt. D., L.L.D., Iowa City, Iowa, formerly minister of the Unitarian church, Davenport, Iowa; author of articles in TEs ANNAIS OP IOWA

Vol. XXI, p. 441 ; Vol. XXIII, p. 79 ; Vol. XXVII, p. 15 ; Vol. XXV, p. 147 : also in The lowa Journal of History and Politics, Vol. XIII, No. 1, p. 112 ; Vol XLIII. No. 3, p. 302; Vol. XLIII, No. 4, p. 388; Vol. XLIV, No. 3, p. 291.

g“History of Davenport and Scott County," by Downer, pp. 664 ff.
} 
General Roberts was born in Vermont ${ }^{3}$ and was graduated from West Point in 1835, and soon afterwards turned up as a second lieutenant at Fort Des Moines, in what is now Iowa. He was a flashing young officer just in from the east; but Col. Stephen W. Kearney in command at Fort Des Moines soon took the most of that off him, including a luxuriant beard of which the young lieutenant was visibly proud. In 1839 he resigned from the army and devoted his engineering training to civil undertakings, including railroad building in northern New York. In 1842 he accepted an offer from the government of Russia to engage in railroad construction. Upon his arrival over there it was demanded that he take an oath of allegiance to the Tsar's government, which he refused to do. Roberts returned to the United States and to Iowa, where he settled in Fort Madison and where he was admitted to the bar and entered into the practice of law.

\section{ROBERTS IN MEXICAN WAR}

At the outbreak of the War with Mexico he immediately returned to the army as a captain. He was present at the capture of Vera Cruz and moved on to the attack on Mexico City, his record including Cerro Gordo, Cherubusco, and finally the capture of the capital itself. Captain Roberts was designated by General Scott to lead the first troops into Mexico City and to raise the first United States flag over the ancient castle, The Chapultepec.

Both he and his adopted state showed complimentary appreciation to each other. Roberts picked up an ancient suit of Spanish armor in Mexico, in three pieces, helmet, breast plate and back plate, the whole fantastic business weighing about thirty-five pounds, which he sent back to Iowa as a present. It is preserved in the library of the State Historical Society in Iowa City.

${ }^{3}$ The Palimpsest, Vol. I, Article on Gen. B. S. Roberts, by Miss Ruth Gallaher, pp. 75 ff. THE ANNALS OP IOWA, Vol. 1, First Series, pp. 200 ff.; Vol. XXVIII, pp. 81 ff. 
With the armor was sent a sword which seems to have disappeared a few years later and still remains among the unknown. In Volume I, First Series of THE ANNALS OF IoWA, (January 1864) is an article on Gen. eral Roberts by the then editor, T. S. Parvin, in which there is included a portion of a letter by Roberts under date of December 15, 1863, to the librarian of the State Historical Society, the Rev. S. S. Howe. Mr. Howe had advised General Roberts in Davenport that he thought he had recognized the sword. Roberts wrote a description of it, as being a slightly curved instrument of war, with a basket hilt, inlaid with silver. There are a few unidentified swords in a display case in the library of the State Historical Society, but none of them sufficiently answers this description to make an exact identification.

In the letter Roberts explains briefly how he came by the sword. With a force of seven hundred men he was chasing the Mexican guerilla chief, General Torrejon, and his men, on the tenth of November, 1847. The Mexicans were running their horses up a mountain path with Roberts and his men in close pursuit and gaining on them. Torrejon hard pressed, abandoned his horse and took to his feet up a goat path where the Americans could not follow. According to the custom of the Mexican cavalry, the sword was attached to the saddle, and Torrejon did not stop to unhook it. Roberts took it as he came up to the horses the Mexicans had left behind.

The General Assembly of Iowa, Jan. 15, 1849, voted an appropriation to purchase a sword as a gift to Colonel Roberts (he came out of the war with that rank). The sword was presented to him in Washington by Iowa's representatives in the Congress. It remains in that city.

Following the fighting with Mexico Roberts returned to Fort Madison and his profession. When the Civil war broke out he again entered into military life. He was at first assigned to Fort Stanton' in New Mexico, in 1861. In 1862 he was promoted to be a brigadier

'Tue ANnals of Iowa, op. cit. 
general of volunteers. In May 1863 he was designated to take command of the Iowa District with headquarters in Davenport where his office was in the Metropolitan building at the southeast corner of Second and Brady streets. The camp under his command was christened for him while he was in Davenport.

He was in Davenport only a few months, as in in December of the same year he was transferred to the Department of The Gulf. It does not appear that he returned to Iowa to live after the war was over. He remained in the regular army and died in Washington January 29, 1875.

\section{CAMP RENAMED FOR COLONEL KINSMAN}

Camp Roberts was afterward renamed for Col. William H. Kinsman, another adopted son of Iowa. Colonel Kinsman was born in New Scotia in $1834 . .^{\circ}$ He was possessed by the spirit of adventure from his boyhood; at the age of fifteen he went to sea on a windjammer. Four years later he was in New York a student at the Claverack College and Hudson River Institute from which he was graduated about $1857 .^{\circ}$ We find him later in Cleveland engaged in newspaper work, and in the study of law, which did not take much effort in those days. He was soon off again, for more westerly scenes. This time he got beyond the railroad limits and crossed Iowa on foot. He got to Council Bluffs in 1858 without any money. There he taught school some, wrote for the local newspaper, and after he had been admitted to

EThe ANNALs of Iowa, Vol. V, pp. 241 ff.

"Iowa Colonels and Regiments," by Stuart, pp. 383 ff.

"Aurner's "History of Education in Iowa," p. 335. See also Stuart, op. cit.

This reference comes close home to me for I was born in Hollowville, New York, about three miles from the village of Claverack, the site of the ochool in question, which was still going in my boyhood. It dated back as Washington Seminary to 1777, the year of Burgoyne's surrender to Gates some fifty or more miles north of Claverack. One of the young impressed British soldiers in the Burgoyne army went down to Washington Seminary as an instructor and in a few years became principal of the school. He was Dr. Andrew M. Carshore. He held the office for twenty-five years or so. The name of the school was changed to include the title of "college", but it was in reality a preparatory school, in which function it had a long and honorable career. About 1900 it went the way of many such private schools in competition with public high schools. The name "Claverack" is a Dutch word applied to the region by Henry Hudson in 1609, when he and his Half Moon made their way up the river named in honor of its first white explorer. The word means "clover reaches" or "clover meadows", as Hudson saw the valley fields all abloom. 
the bar became associated with the law firm of Clinton and Bartlett. Later that year the lure of Colorado and its gold was attractive in Kinsman's sight and he was off again, this time to Pike's Peak; but he didn't stay long. Returning to Council Bluffs he settled in the practice of law with Col. D. C. Bloomer, whose name is preserved in none of his professional activities but in a peculiar garment devised for feminine wear by Mrs. Bloomer, who had gone sour on the prevailing styles.

Kinsman was active in the Lincoln campaign of 1860 and in the military company, the Council Bluffs Guards, whose captain was Grenville M. Dodge. When the nation was ripped in two by the shooting at Fort Sumter, the guards were called into action. Kinsman went out as a second lieutenant. His early service was in the Missouri area, at Pea Ridge and in the campaign of which it was a part. His promotions were rapid, and he was soon in command of the Fourth Iowa regiment and later of the Twenty-third. He was a dashing officer, always preceding his regiment in attack, with drawn sword held high and with urgent voice shouting his men on. In 1863 he and his regiment were transferred to the Vicksburg campaign, where in a charge on a breastworks he was fatally wounded. The story goes that he had a premonition that that battle would be his last and confided it to some of his friends, asking them to see that he be buried on the battlefield. Colonel Kinsman died May 18, 1863.

General Dodge, who wrote the memoirs of Kinsman in ThE ANNALS OF IowA, Vol. V., later started a movement for the removal of the remains to Council Bluffs, which finally occurred in 1902.

\section{IOWA'S DeBT to ANNIE WITTENMEYER}

After General Roberts left Iowa for the Gulf Region, the camp in Davenport was renamed in honor of the dead Colonel Kinsman, and continued as such until it was abandoned. Before the noise and smoke died away, however, a movement was under way that was destined 
to change the function of the place from that of training young men in the ways of war to that of training boys and girls in the ways of peace and righteousness.

Out of Keokuk had come that flaming angel, the Florence Nightingale of Iowa, Mrs. Annie Wittenmeyer, to whose memory Iowa has never given fitting tribute. She made the care of wounded soldiers her commanding purpose in life. Governor Kirkwood appointed her "State Sanitary Agent". By a natural route of quick comprehension her ready mind passed from the dead men in blue uniforms to their families back in the towns and on the farms of Iowa. That comprehension gave birth to her idea of a home or homes for the care of the orphaned children of those soldiers. When Mrs. Wittenmeyer laid hold on such a project she knew no stopping place.

A meeting was held in Iowa City September 23, 1863, to get something started; and at subsequent meetings in Muscatine on October 5th, and in December of that year, an organization was set up to carry on the project, under the name of "The Iowa Soldiers' Orphans Association." The start was made in a rented home in Farmington, Van Buren county, in 1864, and a second home was opened in Cedar Falls in 1865. By September of that year both homes were full.

When Camp Kinsman was abandoned by the army, its barracks or cottages stood empty. It occurred to Mrs. Wittenmeyer that here was the ready-made place for the orphans' home, if the war department could be made to see it. Mrs. Wittenmeyer posted off to Washington with her unabated energy and persuasive powers.

In her book "Under The Guns" Mrs. Wittenmeyer describes her visits at various offices and finally armed with written statements from different army officers a visit to the secretary of war, Edwin M. Stanton, whose interest proved to be quick and deep. Her request included requisitions for hospital supplies, blankets, sheets,

Downer, op cit. 
pillows, pillow cases, "and so on to everything I could remember that could be of use to the home were enumerated." With the recommendations of Stanton, the surgeon general and the quartermaster general, final action for transfer of the property must be taken by the congress. Senator James W. Grimes, of Burlington, and Congressman Hiram Price, of Davenport, quickly and effectively took hold of the project and congressional action moved rapidly. The property was transferred to the society. The gift from the government included 273 acres of land and an estimated $\$ 27,000$ in movable property.

With all of this property in their hands the society had to undertake extensive repairs and large quantities of additional equipment. A financial campaign in Davenport and Scott county was started in October, 1865. Judge John F. Dillon was made chairman of the campaign setup. The Davenport papers for October and November, 1865 , carry the stories of the subscriptions as they came in from the city and from the towns of the county. Finally, these subscriptions seem to have totalled some forty thousand dollars. The story of the proposed home was taken to the Iowa soldiers, some themselves in hospitals. The project caught their sympathetic imagination and some fifty thousand dollars come from them.

The work of repairs went on rapidly and equipment was secured. The home was put in use in November before the work was done, however, when the one hundred fifty children in the home in Farmington were moved to Davenport.

With all of this additional opportunity to care for the children, the distances in Iowa were another problem. The part of the state on the Missouri had its necessities too. In 1866 a third home was established in Glenwood. The project had outgrown the plans of its promoters, to whom came the suggestion that it ought to be a state undertaking. The general assembly of Iowa of 1865 SSee The Journal of History and Politics, Vol. XVI, pp. 260 ff and Vol. XXIV,
pp. 519 ff. 
had to be shown when the project was presented to its members; but it came up again at the next session when the members saw the light and by virtue of appropriate legislation the property formally passed to the state June 6,1866 , the first institution of its kind under state ownership and direction in the United States. The children in the home at Cedar Falls were moved to Davenport and in 1876 the group at Glenwood followed. The abandonment of those state institutions explains the location of the State Teachers' College at Cedar Falls and of the School For the Feeble Minded at Glenwood, as local substitutes for the orphans' homes.

Into the story of "The Orphans' Home" are woven the names of Roberts and Kinsman, as recognition of their military services; the erosions of time have pretty much buried their names in the debris of fourscore years. There would be nothing to remind Davenport of them now but for the valiant labor of a woman of great soul, who without thought for the names attached to a site of an abandoned camp, moved Iowa to say of innumerable children, "Let them come unto me and forbid them not."

\section{A DUTY OWED TO RISING GENERATION}

Gov. Henry Dodge: I recommend to the legislative assembly, the propriety of asking from congress a donation of one township of land, to be sold, and the proceeds of the sale placed under the direction of the legislative assembly of this territory, for the establishment of an academy for the education of youth; the institution to be governed by such laws and regulations, and to be erected at such place as the legislative assembly may designate. It is a duty we owe to the rising generation to endeavor to devise means to improve the condition of those that are to succeed us; the permanence of our institutions must depend upon the intelligence of the great mass of the people.-First Annual Message, Oct. 26, 1836 , to the Territorial Legislative Assembly, Territory of Wisconsin. 
Copyright of Annals of Iowa is the property of State of Iowa, by \& through the State Historical Society of Iowa and its content may not be copied or emailed to multiple sites or posted to a listserv without the copyright holder's express written permission. However, users may print, download, or email articles for individual use. 